DOI https://doi.org/10.30525/978-9934-588-92-1-80

\title{
АКТУАЛЬНІ ПИТАННЯ КЛАСИФІКАЦЇ̈ КРИМІНАЛЬНИХ ПРАВОПОРУШЕНЬ ЗА СТУПЕНЕМ ТЯЖКОСТІ
}

\author{
Охман О. В. \\ кандидат юридичних наук, \\ доиент кафедри права та правоохоронної діяльності \\ Хмельницького інституту імені Блаженнійшого Володимира, \\ Митрополита Київського і Всієї України \\ ПрАТ «ВНЗ «Міжрегіональна Академія управління персоналом» \\ м. Хмельницький, Україна
}

3 набранням чинності Закону України «Про внесення змін до деяких законодавчих актів України щодо спрощення досудового розслідування окремих категорій кримінальних правопорушень» від 22.11.2018 р. № 2617-VIII [1], постає актуальним питання нового розгляду класифікації кримінальних правопорушень за ступенем тяжкості. За останній період часу все частіше почали 3'являтися дослідження українських науковців пов'язані із проблематикою класифікації кримінальних правопорушень. На нашу думку, такий інтерес вітчизняних правознавців пов'язаний із реформуванням кримінального законодавства України та введенням до структури Кримінального кодексу України інститутів кримінального проступку та кримінального правопорушення. У багатьох дослідженнях присутній порівняльний аналіз законодавства про кримінальну відповідальність закордонних країн та України, але дослідження нової класифікації кримінальних правопорушень не проводилось. Серед різноманітних кримінальноправових класифікацій кримінальних правопорушень на особливу увагу заслуговує їх законодавчий поділ за ступенем тяжкості, закріплений у ст. 12 КК України [2].

Варто погодитись із Н.А. Орловською, яка зазначає, що: «використання ступеня тяжкості як класифікаційної ознаки $є$ розвитком позиції законодавця щодо суспільної небезпечності діяння, кількісна характеристика якої має відображати співвідношення злочинів одного характеру суспільної небезпечності» [3, с. 274]. Тобто, для детального розгляду конкретного кримінально протиправного діяння, 3 метою ефективного пошуку заходів протидії, виникає необхідність класифікації кримінальних правопорушень за ступенем тяжкості. 
Із внесеними змінами, ст. 12 Кримінального кодексу України, що встановлювала класифікацію всіх злочинів, зазнала найбільшого оновлення. Кримінальні правопорушення тепер поділяються на кримінальні проступки та злочини. Тобто, відбулася зміна термінів i тепер ми маємо поняття «кримінальне правопорушення», «кримінальна протиправність», «кримінальний проступок» тощо. Такі зміни відбулися чи не у кожній статті КК України, а поняття «злочин» набуло вузького значення. У ч. 2 ст. 12 КК України зазначено, що кримінальним проступком $\epsilon$ передбачене КК України діяння (дія чи бездіяльність), за вчинення якого передбачається основне покарання у вигляді штрафу в розмірі не більше трьох тисяч неоподатковуваних мінімумів доходів громадян (51 тис. грн.) або інше покарання, не пов'язане з позбавленням волі.

Злочини, за новою класифікацією, поділяються на нетяжкі, тяжкі та особливо тяжкі:

- Нетяжким злочином є діяння (дія чи бездіяльність), передбачене КК України, за вчинення якого встановлюється основне покарання у виді штрафу в розмірі не більше десяти тисяч неоподатковуваних мінімумів доходів громадян (170 тис. грн.) або позбавлення волі на строк не більше п'яти років (ч. 4 ст. 12 КК України).

- Тяжким злочином $є$ діяння (дія чи бездіяльність), передбачене КК України, за вчинення якого встановлюється основне покарання у виді штрафу в розмірі не більше двадцяти п'яти тисяч неоподатковуваних мінімумів доходів громадян (425 тис. грн.) або позбавлення волі на строк не більше десяти років (ч. 5 ст. 12 КК України).

- Особливо тяжким злочином є діяння (дія чи бездіяльність), передбачене КК України, за вчинення якого встановлюється основне покарання у виді штрафу в розмірі понад двадцять п'ять тисяч неоподатковуваних мінімумів доходів громадян або довічного позбавлення волі (ч. 6 ст. 12 КК України).

У разі передбачення в санкції статті одночасно основного покарання у виді штрафу та позбавлення волі, під час визначення ступеня тяжкості злочину слід виходити зі строку покарання у виді позбавлення волі. Таким чином, бачимо, що зі звичної класифікації злочинів зникла категорія злочинів середньої тяжкості, а частина злочинів невеликої тяжкості перейшла в категорію кримінальних проступків. Погоджуємось 3 думкою В. І. Лутчина, який зазначає, що дані зміни у кримінальному законодавстві покликані призвести його у відповідність до європейського законодавства [4, с. 117]. 
Тяжкість кримінального правопорушення впливає на все, починаючи від термінів погашення судимості, залежно від тяжкості вчиненого кримінально протиправного діяння, застосування процедур звільнення від кримінального покарання, питань, пов'язаних із застосування запобіжних заходів і негласних слідчих чи розшукових дій, а також на можливості міжнародного співробітництва.

Р. Оксанич зазначає: «що недоліком Закону є відсутність чіткої регламентації започаткування інституту дізнання та необхідного алгоритму дій для органів досудового розслідування та суду у зв'язку із запровадженням інституту кримінальних проступків, а саме: процедури передачі кримінальних проваджень від слідчих дізнавачам, дії прокурора та суду під час підготовки, отримання, прийняття до провадження обвинувальних актів тощо» [5]. Також, О.В. Сачко вказує: «що запровадження в слідчу і судову практику інституту кримінальних проступків потребує забезпечення їх чіткої юридичної визначеності, узгодження з конституційними принципами правосуддя взагалі» [6]. На нашу думку, кардинальна зміна засад кримінальноправової політики в частині запровадження інституту проступку повинна відповідати принципу наступності законодавства, базуватися на фундаментальних наукових дослідженнях, обговорюватися на численних науково-практичних конференціях.

На думку Г. С. Крайник та К. В. Ципищук: «поява кримінального проступку в кримінальному законодавстві України $\epsilon$ взагалі недоцільним» [7, с. 216]. Однак, на нашу думку, кримінальний проступок, який вчинений вперше надасть можливість суду застосовувати інститут звільнення від кримінальної відповідальності, повторно вчинений кримінальний проступок, відповідно, буде виключати можливість застосування цього інституту. Повторність проступку та повторність злочину повинні мати самостійне значення, а рецидив має бути лише при вчинені повторного умисного кримінального правопорушення після засудження за перше умисне кримінальне правопорушення, якщо судимість за нього не була знята або погашена. Призначене за кримінальний проступок покарання не породжує судимості, а до неповнолітніх, які вчинили проступок вперше, можуть бути застосовані лише примусові заходи виховного характеру.

Враховуючи все вищесказане, безсумнівно, запровадження нової класифікації кримінальних правопорушень за ступенем тяжкості - $\epsilon$ важливою частиною реформування кримінального законодавства України до вимог реалій життя суспільства. Тобто гуманізація кримінальної відповідальності та спрощення процедури притягнення до кримінальної відповідальності цілком необхідна, однак, зміни до 
кримінального законодавства, що стосуються можливості затримання осіб за вчинення кримінальних проступків та повернення органів дізнання у кримінальний процес, залишають багато відкритих запитань для всіх учасників кримінального провадження. Дані питання класифікації кримінальних правопорушень за ступенем тяжкості, потребують подальших детальних наукових досліджень, прийняття нових та вдосконалення раніше прийнятих та чинних нормативноправових актів.

\section{Література:}

1. Про внесення змін до деяких законодавчих актів України щодо спрощення досудового розслідування окремих категорій кримінальних правопорушень: Закон України від 22.11.2018 р. № 2617-VIII. Набрання чинності: 01.07.2020 p. URL: https://zakon.rada.gov.ua/laws/show/2617-19

2. Кримінальний кодекс України: прийнятий від 05.04.2001 p. № 2341-III. Дата оновлення: 03.09.2020 p. URL: https://zakon.rada.gov.ua/ laws/show/2341-14

3. Орловська Н.А. Актуальні питання класифікації злочинів за ступенем тяжкості. Кримінальне право в умовах глобалізаиії суспільних процесів: традииї та новації: матеріали міжнар. наук.-практ. круглого столу, м. Харків, 15 трав. 2020 р. / [редкол.: В.Я. Тацій (голов. ред.), Л.М. Демидова (заст. голов. ред.), А.П. Гетьман та ін.]. Харків : Право, 2020. 776 c. С. $274-278$.

4. Лутчин В.І. Критерії класифікації кримінальних правопорушень за кримінальним правом України та Республіки Польща. Вчені записки ТНУ імені B.I. Вернадського. Серія: юридичні науки. 2 Том 29 (68). № 6. 2018. C. 112-118.

5. Оксанич Р. Інституту кримінальних проступків зелене світло? Юридична газета online. 2017. URL: https://yur-gazeta.com/dumkaeksperta/institutu-kriminalnih-prostupkiv-zelene-svitlo.html

6. Сачко О.В. Верховенство права під час застосування інституту дізнання щодо кримінальних проступків. Приватне та публічне право. № 4. 2018. С. 67-70.

7. Крайник Г.С., Ципищук К.В. Щодо недоцільності появи «кримінального проступку» в кримінальному законодавстві України. Молодий вчений. № 1 (77). Січень. 2020 р. С. 216-219. URL: http://molodyvcheny.in.ua/files/journal/2020/1/47.pdf 